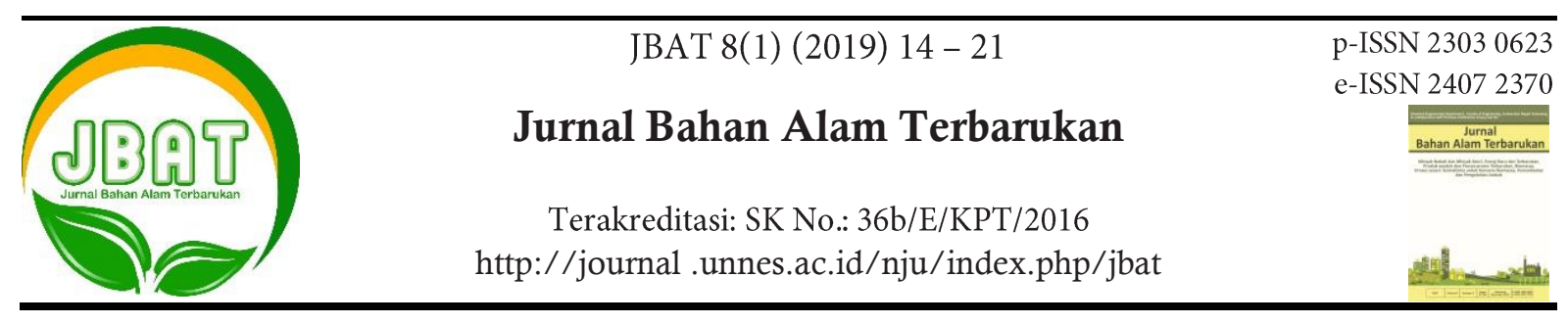

\title{
Inoculum Selection and Micro-Aeration for Biogas Production in Two-Stage Anaerobic Digestion of Palm Oil Mill Effluent (POME)
}

\author{
Sri Ismiyati Damayanti ${ }^{1,2}$, Dian Fitriani Astiti ${ }^{1}$, Sarto $^{1,3}$, Wiratni Budhijanto ${ }^{1,4, \varpi}$
}

DOI 10.15294/jbat.v8i1.16318

${ }^{1}$ Department of Chemical Engineering, Universitas Gadjah Mada, 55281 Yogyakarta, Indonesia

${ }^{2}$ Department of Chemical Engineering, Universitas Lampung, Indonesia

${ }^{3}$ Energy and Environment Group, Universitas Gadjah Mada, 55281 Yogyakarta, Indonesia

${ }^{4}$ Bioresource Engineering Group, Universitas Gadjah Mada, 55281 Yogyakarta, IndonesiaChemical

\begin{tabular}{|c|c|}
\hline Article Info & Abstract \\
\hline $\begin{array}{l}\text { Article history: } \\
\text { Received } \\
\quad \text { October } 2018 \\
\text { Accepted } \\
\quad \text { June } 2019 \\
\text { Published } \\
\quad \text { June 2019 } \\
\text { Keywords : } \\
\text { Biogas; } \\
\text { POME; } \\
\text { Two stage anaerobic } \\
\text { digester; } \\
\text { Inoculum; } \\
\text { Micro-aeration }\end{array}$ & $\begin{array}{l}\text { Two-stage anaerobic fluidized bed is an innovation in anaerobic digestion technology } \\
\text { intended to handle liquid waste with high organic loading and complex substrate. The } \\
\text { process is based on separation between acidogenic/acetogenic and methanogenic processes. } \\
\text { The first stage is anaerobic process to convert substrate (represented as soluble chemical } \\
\text { oxygen demand/sCOD) into volatile fatty acids (VFA). The second stage is methanogenic } \\
\text { process to convert VFA into biogas. This study aimed to separate acidogenic/acetogenic and } \\
\text { methanogenic processes by means of limited injection of air (micro-aeration) and inoculum } \\
\text { selection. Micro-aeration was introduced in acidogenic/acetogenic stage because the relevant } \\
\text { microbes were facultative so that the obligate anaerobic methanogens will be suppressed. On } \\
\text { the other hand, the methanogenic reactor was kept completely anaerobic to ensure } \\
\text { methanogenic dominance over acidogenic/acetogenic ones. Two sources of inoculums were } \\
\text { used in this study, i.e. anaerobically digested biodiesel waste and anaerobically digested cow } \\
\text { manure. Both inoculums were taken from active biogas reactor treating biodiesel waste and } \\
\text { cow manure, respectively. Experiments were run in batch reactors treating palm oil mill } \\
\text { effluent (POME) as the substrate for the acidogenic/acetogenic reactor. After the reaction in } \\
\text { the first stage reached the minimum substrate concentration, the content of the reactor was } \\
\text { used as the substrate for the methanogenic reactor as the second stage. Routine measurements } \\
\text { were taken for sCOD and VFA concentrations, biogas production, and methane } \\
\text { concentration in the biogas. Results confirmed that micro-aeration maintained good } \\
\text { performance of acidogenic/acetogenic process, which was indicated by peaks in VFA } \\
\text { accumulation, while suppressing methanogenic activities as no methane produced in this } \\
\text { stage. Digested biodiesel waste was superior inoculum to be compared to digested cow } \\
\text { manure with respect to sCOD removal. In the methanogenic stage, digested biodiesel waste } \\
\text { also performed better as inoculum as it led to higher VFA conversion, higher biogas } \\
\text { production rate, and higher methane content in the biogas. }\end{array}$ \\
\hline
\end{tabular}

\section{INTRODUCTION}

Palm oil is one of fast growing commodities in Indonesia. In the last 5 years, oil palm plantation in Indonesia has grown as much as $29.8 \%$, from 8.99 million hectares in 2011 to 11.67 million hectare in 2016, with the production capacity of Crude Palm Oil (CPO) reached 30.95 million tonnes (Ministry of Agriculture, 2016).
One of the disturbing wastes emitted by palm oil industries is Palm Oil Mill Effluent (POME). Every ton of CPO production will be accompanied by POME emission as much as 3.05 tonnes (Saelor et al., 2017). POME is difficult to be treated because of its high organic content and acidic pH (Poh \& Chong, 2009). Typical POME contains organic materials represented as Chemical Oxigen Demand (COD) as much as 15,000-100,000

\footnotetext{
${ }^{\square}$ Corresponding author:

Department of Chemical Engineering, Universitas Gadjah Mada, 55281

Yogyakarta, Indonesia

E-mail: wiratni@ugm.ac.id
} 
$\mathrm{mg} / \mathrm{L}$, with the average COD around 51,000 $\mathrm{mg} / \mathrm{L}$. With such a high concentration of organic materials, POME exhibits mesophilic biochemical methane potential (BMP) as much as $0.397 \pm 0.009$ $\mathrm{L} \mathrm{CH} 4 / \mathrm{gVS}$ at $37^{\circ} \mathrm{C}$ (Kim, et al., 2013).

In the last three years, we have been developing Anaerobic Fluidized Bed Reactor (AFBR), especially two-stage AFBR, which separates the acidogenic/acetogenic process in the first stage and followed by methanogenic process in the second stage to improve biogas productivity from POME. Careful $\mathrm{pH}$ control can induce domination of acidogenic/acetogenic in first stage (acidic $\mathrm{pH}$ ) and domination of methanogenic in second stage (neutral $\mathrm{pH}$ ). With such an arrangement, AFBR was proven to be able to handle high organic loading waste water (C. Nicolella et al., 2000; Montalvo et al., 2007).

In AFBR, microorganisms are immobilized on the surface of small particles (biocarriers) fluidized in the reactor. The microorganisms form biofilm which protects them with internal environment which is more conducive due to stable $\mathrm{pH}$, resistance to inhibitor diffusion, and retention to nutrients (Shuler \& Kargi, 2002). Biofilm formation is then quite beneficial for bioprocess in waste treatment because biofilm enables cross-feeding, co-metabolism, and interspecies hydrogen and proton transfers which improves colony stability upon fluctuating conditions in the waste water (Montalvo et al., 2012). Biocarriers also increase Solid Retention Time (SRT) so that their application effectively reduces the risk of microbial washout when the reactor is operated at high feed flow rate (Milán et al., 2010). The features of AFBR make it possible to be operated efficiently and can be designed as vertical column which does not need large land area (Ramadhani et al., 2018).

Two-stage anaerobic reactors with different operating conditions to induce different group of anaerobic microorganism is recommended for substrate with high fat/oil content (Hidalgo et al., 2015). Two-stage reactor is more beneficial to process complex substrate to be compared to single stage reactor because two-stage reactor leads to lower retention time and higher efficiency in biogas formation (Bouallagui et al., 2005; Demirer \& Chen, 2005).

With different groups of microbes expected in each reactors, it is then very crucial to optimize start-up period so that the expected population in each reactor can be stabilized quickly (Alkarimiah et al., 2011). One of the ways to shorten the start-up period is adding inoculum, which is a group of microorganisms from external source (Alkarimiah et al., 2011). Effebi et al. (2011) has used liquid bulk and sediment of anaerobic pond as two different inoculum sources for acidogen and methanogen reactors respectively. Their study concluded that both inoculums led to similar performance in acidogenic/acetogenic reactor while the inoculum from pond sediment showed better performance on methanogenic reactor. This result highlighted the importance of inoculum selection.

This study aimed to compare the performance of two inoculums in acidogenic and methanogenic conditions for anaerobic digestion of POME. The sources of inoculum were the effluents of active biogas digester, i.e. one was the digester treating cow manure and the other was treating the waste of biodiesel plant. To study the possibility of using oxygen to improve acidogenic and methanogenic process separation, a small amount of air (micro-aeration) were injected to the acidogenic/acetogenic stage and its effect on acidogenic and methanogenic process separation was evaluated.

\section{RESEARCH METHODOLOGY}

\section{Materials}

Two inoculum sources were used in this study, i.e. the effluent of active biogas digester treating cow manure (taken from Sleman, Daerah Istimewa Yogyakarta Province) and the effluent of active biogas digester treating biodiesel plant waste (taken from biodiesel plant in East Java Province). As substrate in acidogenic reactor, POME was obtained from Palm Oil Mill Bekri, PTPN VII, Lampung. For methanogenic reactor, the substrate was the outflow from acidogenic reactor. Nitrogen and carbon dioxide was used as flushing gas to ensure anaerobic condition in both reactors prior of experiments. Supporting chemicals for analytical purpose were $\mathrm{H}_{2} \mathrm{SO}_{4} 95$ - 97\% p.a, $\mathrm{HCl} 37-38 \%$ p.a., $\mathrm{NaOH}$ pellet p.a (Merck), $\mathrm{C}_{8} \mathrm{H}_{5} \mathrm{KO}_{4}$ p.a. (EMSURE), $\mathrm{HgSO}_{4}$ p.a (EMSURE), $\mathrm{AgSO}_{4}$ p.a. (Merck), $\mathrm{K}_{2} \mathrm{Cr}_{2} \mathrm{O}_{7}$ p.a (EMSURE), $\mathrm{Na}_{2} \mathrm{~B}_{4} \mathrm{O}_{7} \cdot 10 \mathrm{H}_{2} \mathrm{O}$ 99,5\% (Merck), and $\mathrm{HCl} 37 \%$ p.a (Merck).

The characteristics of POME, digested cow manure inoculum, and digested biodiesel waste inoculum are presented in Tables 1,2 , and 3. 
Table 1. Characteristics of Palm Oil Mill Effluent (POME).

\begin{tabular}{lll}
\hline Parameter & Value & Unit \\
\hline pH & 4 & - \\
Chemical Oxygen & 11,995 & $\mathrm{mg} / \mathrm{L}$ \\
Demand & & $\%$ \\
Protein & 0.15 & $\%$ \\
Nitrogen & 0.0295 & $\%$ \\
Total sugar & 0.314 & $\%$ \\
Fe & 0.258 & $\mathrm{mg} / \mathrm{L}$ \\
Sulfide & 5.8 & $\mathrm{mg} / \mathrm{L}$ \\
Phosphate & 37.175 & $\mathrm{mg} / \mathrm{L}$ \\
Phenol & $\leq 0.0001$ & $\mathrm{mg} / \mathrm{L}$ \\
Nickel & 0.143 & $\mathrm{mg} / \mathrm{L}$ \\
Oil and grease & 115 & $\mathrm{mg} / \mathrm{L}$ \\
Potassium & $1,459.86$ & $\mathrm{mg} / \mathrm{L}$ \\
Sulphate & $1,032.93$ & $\mathrm{mg} / \mathrm{L}$ \\
Ammonia & 125 & $\mathrm{mg} / \mathrm{L}$ \\
\hline \multicolumn{2}{c}{ Source: Halim et al. (2017) } \\
\multicolumn{3}{c}{}
\end{tabular}

Table 1. Characteristics of Digested Biodiesel Waste Inoculum.

\begin{tabular}{lll}
\hline Parameter & Value & Unit \\
\hline $\mathrm{pH}$ & 7,53 & - \\
$\mathrm{TS}$ & 28.26013 & $\mathrm{mg} / \mathrm{L}$ \\
$\mathrm{VS}$ & 13.540 & $\mathrm{mg} / \mathrm{L}$ \\
$\mathrm{VFA}$ & $1.436,74$ & $\mathrm{mg}$ acetic \\
$\mathrm{SCOD}$ & 1.980 & $\mathrm{acid} / \mathrm{L}$ \\
\multicolumn{2}{c}{ Source $:$ Ramadhani et al $(2018)$}
\end{tabular}

Table 3. Characteristics of Digested Cow Manure Inoculum

\begin{tabular}{lll}
\hline Parameter & Value & Unit \\
\hline $\mathrm{pH}$ & 7.5 & - \\
Chemical & 1,250 & $\mathrm{mg} / \mathrm{L}$ \\
$\begin{array}{l}\text { Oxygen Demand } \\
\text { Volatile Solid }\end{array}$ & 34,968 & $\mathrm{mg} / \mathrm{L}$ \\
Volatile Fatty & 201,000 & $\mathrm{mg}$ acetic acid/L \\
Acid & & \\
\hline
\end{tabular}

Source : Damayanti et al. (2018)

\section{Anaerobic digestion}

Four Erlenmeyer flasks were used as batch acidogenic reactors with working volume of 400 $\mathrm{mL}$. The experimental set up was presented in Figure 1. In all flasks, 1.5 gram/L of $\mathrm{Na}_{2} \mathrm{CO}_{3}$ solution was added as buffer solution. Into two flasks, digested biodiesel waste inoculum was added while into the other two flasks, digested cow manure inoculum was added. The amount of inoculum added in each reactor was $100 \mathrm{~mL}$. POME with concentration measured as soluble chemical oxygen demand (sCOD) of 800-1000 $\mathrm{mg} / \mathrm{L}$ was added into each flasks as much as 300 $\mathrm{mL}$.

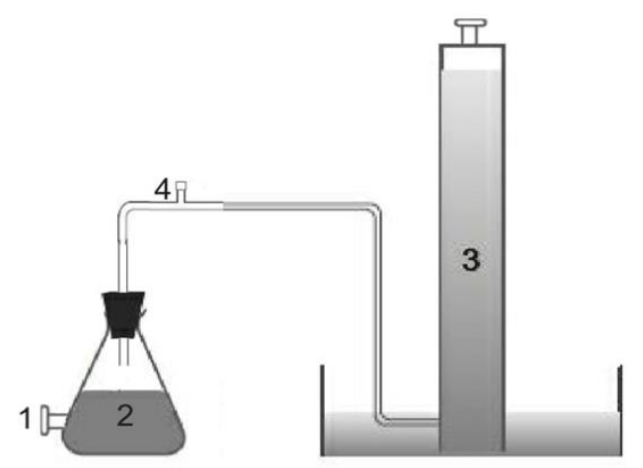

Figure 1. Anaerobic batch digester set up. (1) Liquid sampling point; (2) Gasometer; (3) Digester; (4) Gas Sampling Point.

For each inoculum type, experiments were run at two constant $\mathrm{pH}$ values namely $\mathrm{pH} 4$ and $\mathrm{pH}$ 5. This $\mathrm{pH}$ adjustment was carried out using $\mathrm{HCl}$ and $\mathrm{NaOH}$ solutions. A mixture of $85 \% \mathrm{v} / \mathrm{v} \mathrm{N}_{2}$ and $15 \% \mathrm{v} / \mathrm{v} \mathrm{CO}_{2}$ was bubbled in each flask for 10 minutes before the experiments were started to flush the residual oxygen in the reactor.

To study the role of micro-aeration on acidogenic and methanogenic processes, ambient air was injected once a day with the amount of $5 \%$ of the liquid working volume. The flask was then manually shaken to dissolve the injected oxygen into the liquid. Measured variables reported in this study included $\mathrm{pH}, \mathrm{sCOD}$, volatile fatty acid (VFA), methane production, and anaerobic total plate count. Data collection was stopped when sCOD reached a constant value which was sufficiently lower than the initial sCOD value.

The same procedure was applied on methanogenic reactor. The only differences were the substrate and $\mathrm{pH}$ value. Outlet from acidogenic/acetogenic reactors was used as the substrate in methanogenic stage. The $\mathrm{pH}$ value was increased to the value of 7 by $\mathrm{NaOH}$ solution. In this stage, there was no air injection because methanogens are strictly (obligate) anaerob. Routine sample analysis included sCOD, VFA, biogas volume, and methane content in the biogas. Number of bacteria used as inoculum was determined prior to the experiment. 
Table 4. Number of microorganisms as anaerobic colony forming unit

\begin{tabular}{llcc}
\hline \multirow{2}{*}{ Stage } & \multicolumn{1}{c}{ Inoculum } & \multicolumn{2}{c}{ Anaerobic microbial count (CFU/ml) } \\
\cline { 3 - 4 } & & \multicolumn{1}{c}{ Initial } & Final \\
\hline Acidogenic stage & Digested biodiesel waste & $9.8 \times 10^{2}$ & $9.05 \times 10^{4}$ \\
Acidogenic stage & Digested cow manure & $1.72 \times 10^{4}$ & $1.11 \times 10^{5}$ \\
Methanogenic stage & Digested biodiesel waste & $6.55 \times 10^{4}$ & $5.8 \times 10^{5}$ \\
Methanogenic stage (cow & Digested cow manure & $1.28 \times 10^{5}$ & $4.4 \times 10^{6}$ \\
\hline
\end{tabular}
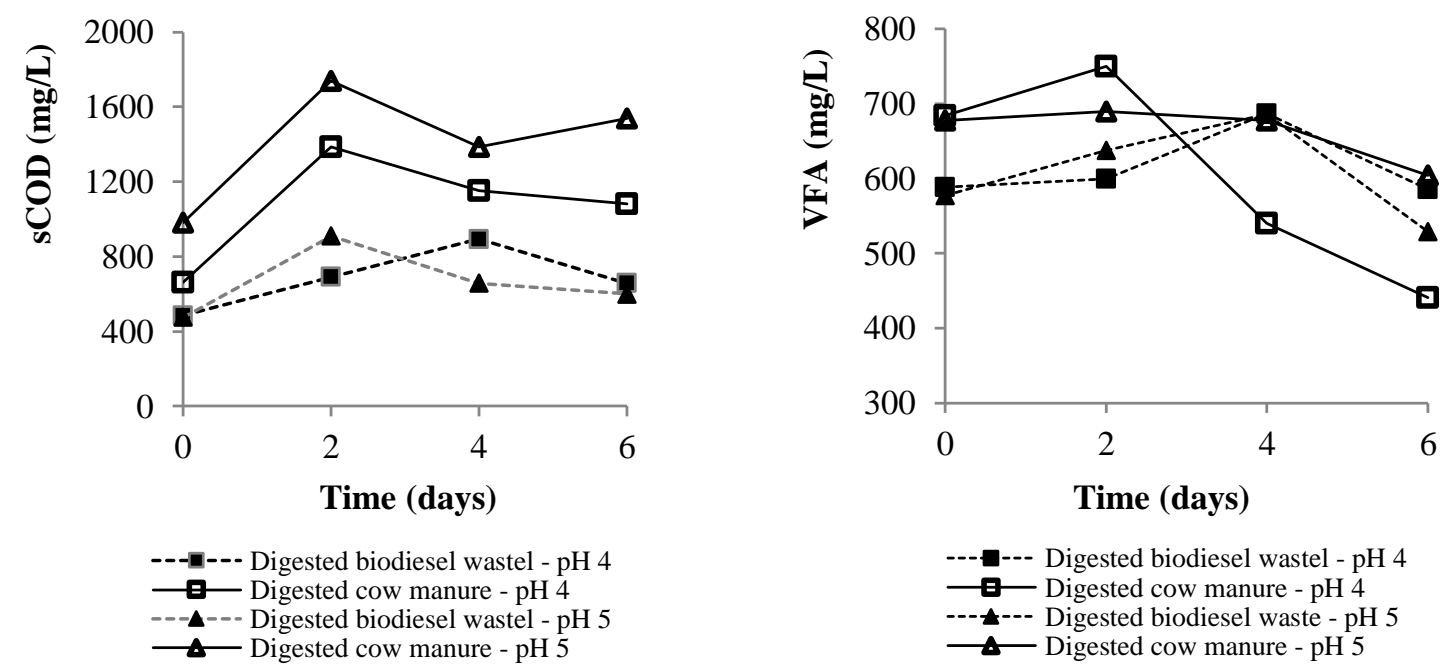

----- Digested biodiesel wastel - $\mathrm{pH} 4$ $\mathbf{0}$ Digested cow manure - $\mathrm{pH} 4$ ---- Digested biodiesel waste - $\mathrm{pH} 5$ $\longrightarrow$ Digested cow manure - $\mathrm{pH} 5$



Figure 2. Profile of anaerobic microorganism parameters in acidogenic/acetogenic reactors with microaeration.

Analysis of sCOD and VFA were conducted by following APHA procedures (Clesceri, et.al., 2005). Methane concentration was measured using Gas Chromatography Shimadzu GC 8A.

\section{RESULTS AND DISCUSSIONS}

\section{Anaerobic microbial growth}

Table 4 presented the numbers of microbes at the beginning and the end of the process. The numbers presented in Table 4 are total bacterial count and could not be separated as acidogenic or methanogenic microbes. Most significant increase was marked on acidogenic stage using biodiesel waste inoculum. It implies that the biodiesel waste inoculum better served the needs in acidogenic stage.

\section{Acidogenic reactor}

Figure 2 shows the profile for sCOD concentration, VFA concentration, and cumulative biogas volume. In Figure $2 \mathrm{a}$, the $\mathrm{sCOD}$ concentration profile indicates that in all reactors, 
Table 5. Performance comparison between inoculums on sCOD removal in acidogenic stage (with microaeration).

\begin{tabular}{lcc}
\hline Inoculum & Initial Acidogenic $\mathrm{pH}$ & $\begin{array}{c}\text { sCOD removal/Initial CFU } \\
\left(\mathrm{mg} \mathrm{sCOD} / 10^{6} \mathrm{CFU}\right)\end{array}$ \\
\hline Digested biodiesel waste & 4 & 30,600 \\
Digested biodiesel waste & 5 & 51,000 \\
Digested cow manure & 4 & 11,600 \\
Digested cow manure & 5 & 17,500 \\
\hline
\end{tabular}

during the first 2 days, increase in sCOD concentration was observed due to the activity of hydrolytic microorganisms which still produced hydrolysates. After day 2, the values of sCOD concentration started decreasing as a sign of acidogenic/acetogenic activity. This activity was also indicated by increasing values of VFA, which was the product of acidogenic/acetogenic microorganisms.

However, this tendency did not happen in the reactor with digested cow manure inoculum. In all reactors using digested cow manure, VFA value immediately decreased on the second day. Quick reduction of VFA was an indication that methanogen consumption on VFA was faster than the production of VFA by acidogenic/acetogenic microbes. According to Table 2, digested cow manure contained more anaerobic microbes than the digested biodiesel waste. This explains the fast consumption of VFA by the methanogenic microbes.

Table 5 lists the value of sCOD removal for all reactors, which is normalized by dividing it with the initial numbers of microbes. The values of sCOD removal was defined as the difference between the highest SCOD concentration and the sCOD concentration values at the end of experiment. Although the numbers of microorganism in biodiesel waste inoculum was lower than that of cow manure inoculum, the rate of SCOD removal with digested biodiesel waste inoculum was about 2-3 times higher than the other inoculum. This preliminary result suggests that digested biodiesel waste was more effective in acidogenic/acetogenic stage for anaerobic digestion of POME, regardless the $\mathrm{pH}$ values, as long as the $\mathrm{pH}$ was still acidic. This finding is reasonable considering that the main substrate for biodiesel digester is similar to the content of POME.

The effectiveness of limited and controlled air injection (microaeration) is shown by the VFA profile in Figure $2 b$ and biogas production in Figure 2c. Microaeration was meant to improve VFA production and its success was shown by peaks observed in VFA concentrations in all reactors injected with micro-aeration. Biogas was form in this stage, but only in very small amount (Figure 2c).

An anomaly was observed in Figure 2c that the reactor with digested cow manure at $\mathrm{pH}$ value of 4 did not produce biogas at all, while the values of SCOD and VFA decreased with the same trend as the other reactors in this experiment. This set of data for the reactor with digested cow manure at $\mathrm{pH}$ 4 were then considered as abnormality that might be due to undetected gas leakage in the reactor.

Gas analysis confirmed that no methane present in the biogas for all acidogenic experiments with micro-aeration. The gas produced was only $\mathrm{CO}_{2}$, which was normal as the product of microorganism metabolism. This fact is an indication that methanogenic process was successfully suppressed by the presence of oxygen in limited amount while the acidogenic/acetogenic process, with the facultative microbes, was enhanced with micro-aeration.

\section{Methanogenic reactor}

All methanogenic reactors were run at neutral $\mathrm{pH}$ and under strictly anaerobic condition without micro-aeration. The substrate was the result from acidogenic/acetogenic reactors. It turned out that the acidogenic/acetogenic results were still containing significant amount of SCOD so that in the methanogenic reactors there was also acidogenic/acetogenic process to convert sCOD into VFA as shown in Figure 3a. With respect to sCOD removal, Figure $3 \mathrm{a}$ indicates that digested biodiesel waste inoculum led to higher efficiency in sCOD removal.

As for VFA concentration profile in Figure $3 \mathrm{~b}$, there are no peaks observed like those in acidogenic/acetogenic reactors (Figure $2 b$ ). This is an indication that methanogenic activity was more dominant than acidogenic/acetogenic activity. In the VFA conversion into biogas, it is shown in Figure $3 b$ that digested biodiesel waste inoculum 


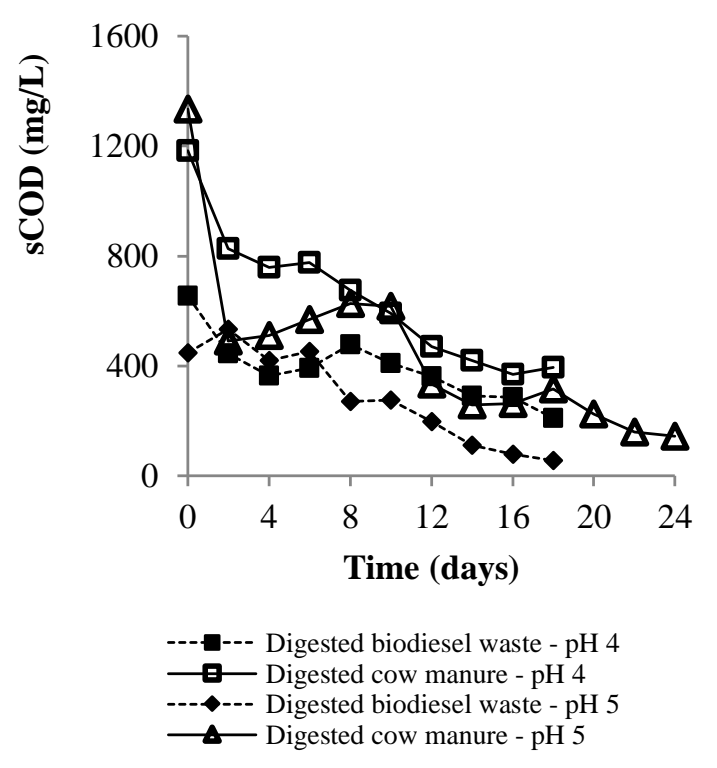

(a)
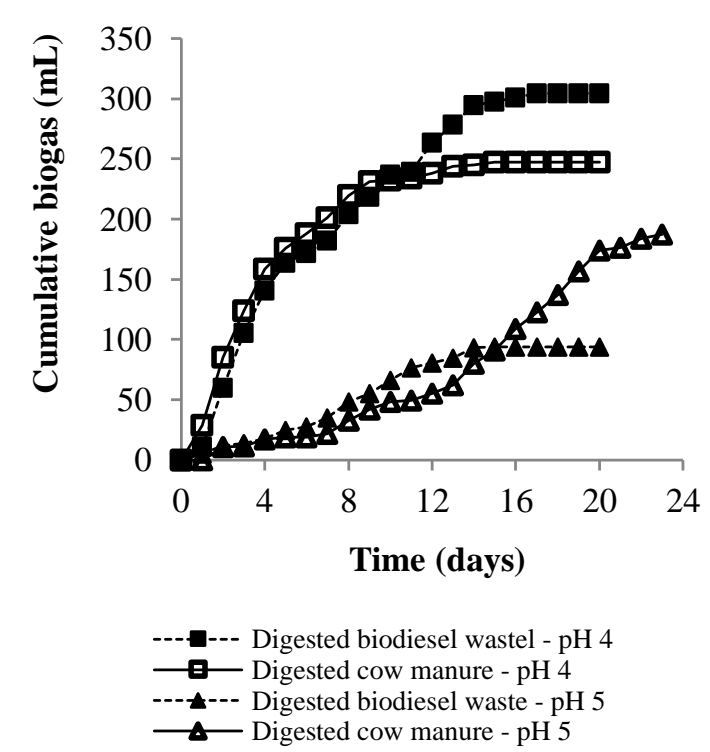

(c)

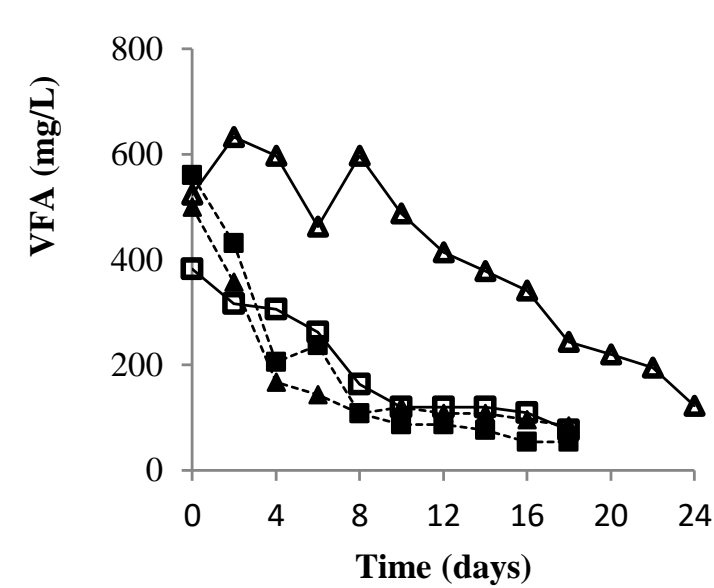

------ Digested biodiesel waste - $\mathrm{pH} 4$

$-\mathbf{\theta}$ Digested cow manure - $\mathrm{pH} 4$

----- Digested biodiesel waste - pH 5

$\longrightarrow$ Digested cow manure - $\mathrm{pH} 5$

(b)



(d)

Figure 3. Profile of anaerobic microorganism parameters in methanogenic reactors

Table 6. Performance comparison between inoculums on VFA removal in methanogenic stage.

\begin{tabular}{lcc}
\hline Inoculum & Initial Acidogenic $\mathrm{pH}$ & $\begin{array}{c}\text { VFA removal/Initial CFU } \\
\left(\mathrm{mg} \mathrm{sCOD} / 10^{6} \mathrm{CFU}\right)\end{array}$ \\
\hline Digested biodiesel waste & 4 & 8,400 \\
Digested biodiesel waste & 5 & 6,900 \\
Digested cow manure & 4 & 2,300 \\
Digested cow manure & 5 & 3,500 \\
\hline
\end{tabular}

converted VFA more effectively than digested cow manure inoculum.

In order to compare the performance of both inoculum in the methanogenic reactors, Table 6 presents the value of VFA conversion for all reactors, which is normalized by dividing it with the initial numbers of microbes. It is obvious from the comparison in Table 6 that digested biodiesel waste inoculum led to higher VFA conversion into biogas. This fact is well supported by the data of biogas production in Figure 3d. Digested biodiesel waste inoculum at initial $\mathrm{pH} 4$ produced highest amount of biogas with highest methane content as well. In methanogenic reactors, $\mathrm{pH}$ was more influential 
than in acidogenic/acetogenic reactors. It is necessary to note then that $\mathrm{pH}$ control is very essential for methanogenic reactor.

\section{CONCLUSION}

Process innovations, i.e. inoculum selection and micro-aeration, were studied to improve the efficiency of anaerobic digestion of POME to produce biogas in two-stage reactor. The results of this preliminary study are outlined as follows.

In acidogenic/acetogenic reactor, digested biodiesel waste inoculum performed better than digested cow manure inoculum with respect to sCOD removal per colony forming unit (CFU) of microbial presence. In methanogenic reactor, biodiesel waste inoculum also gave highest biogas production and highest methane content as well. The values of $\mathrm{pH}$ affected methanogenic reactor more significantly than acidogenic/acetogenic reactors. Nevertheless, for acidogenic/acetogenic process to proceed optimally, reactor $\mathrm{pH}$ had to be maintained at acidic condition. The sensitivity of methanogenic reactor to $\mathrm{pH}$ value suggested that $\mathrm{pH}$ control would be more essential in methanogenic reactor. Micro-aeration in acidogenic reactors successfully suppressed methanogenic activity, which led to more efficient acidogenic/acetogenic activity. Further study is required to define the accurate amount of oxygen to be injected so that the facultative acidogenic/acetogenic microbes perform more efficiently.

\section{ACKNOWLEDGMENT}

The authors convey their appreciation to the Directorate of Research and Community Service, Ministry of Research, Technology, and Higher Education (DPRM Kemenristekdikti) through the program of Hibah Penelitian Tim Pascasarjana, fiscal year of 2018 and Badan Pengelola Dana Perkebunan Kelapa Sawit (BPDPKS) fiscal year 2015 for the financial supports to conduct this research.

\section{REFERENCES}

Alkarimiah, R., Mahat, S. B., Yuzir, A., Din, M. F., \& Chelliapan, S. 2011. Performance of an innovative multi-stage anaerobic reactor during start-up period. African Journal of Biotechnology. 10(54): 1129411302.

Bouallagui, H., Touhami, Y., Cheikh, R. Ben, Hamdi, M. 2005. Bioreactor performance in anaerobic digestion of fruit and vegetable wastes. Process Biochemistry. 40: 989-995.

Cleseri, L. S., Greenberg, A. E., Eaton, A. D. 2005. Standard Methods for the Examination of Water and Wastewater, American Public Health Association (APHA). Washington D.C

Damayanti, S. I., Ginting, S. B., Sofyan, A. V., Putri, A. T., Budhijanto, W. 2018. Utilization of Lampung Natural Zeolite as Immobilization Media on Biogas Production from Palm Oil Mill Effluent ( POME). Material Science Forum. 929: 1826.

Demirer, G. N., Chen, S. 2005. Two-phase anaerobic digestion of unscreened dairy manure. Bioprocess Chemistry. 40: 35423549.

Effebi, K. R., Baya, T., Jupsin, H., Vasel, J. L. 2011. Acidogenic and Methanogenic activities in Anaerobic Ponds. International Journal of Scientific \& Engineering. 2(12): 1-4.

Halim, L., Mellyanawaty, M., Cahyono, R. B., Sudibyo, H., Budhijanto, W. 2017. Anaerobic Digestion of Palm Oil Mill Effluent with Lampung Natural Zeolite as Microbe Immobilization Medium and Digested Cow Manure as Starter. In AIP Conference Proceeding, 1840.

Hidalgo, D., Gomez, M., Martin-Marroquin, J.M., Aguado, A., Sastre, E. 2015. Two-phase anaerobic co-digestion of used vegetable oils ' wastes and pig manure. International Journal of Environmental Science and Technology. 1727-1736.

Kim, S., Choi, S., Ju, H., Jung, J. 2013. Mesophilic co-digestion of palm oil mill effluent and empty fruit bunches. Environmental Technology. 34: 2163-2170.

Milán, Z., Montalvo, S., Ilangovan, K., Monroy, O., Chamy, R., Weiland, P., Borja, R. 2010. The Impact of Ammonia Nitrogen Concentration and Zeolite Addition on The Spesific Methanogenic Activity of Granular and Flocculent Anaerobic 
Sludges. Journal of Environmental Science and Health. 45(7): 883-889.

Ministry of Agriculture, I. 2016. Directorate General of Estate Crops, Agriculture Mof. Tree Crop Estate Statistics of Indonesia 2015 - 2017. Palm Oil. Indonesia. Jakarta.

Montalvo, S., Ferna, F., Guerrero, L., Corte, I., Echeverr1, A. 2007. Real evidence about zeolite as microorganisms immobilizer in anaerobic fluidized bed reactors. Process Biochemistry. 42: 721-728.

Montalvo, S., Guerrero, L., Borja, R., Sánchez, E., Milán, Z., Cortés, I., De, M. A. 2012. Applied Clay Science Application of natural zeolites in anaerobic digestion processes: A review. Applied Clay Science. 58: 125-133.

Nicolella, C., Loosdrecht, M. C. M. van, J.J. Heijnen. 2000. Wastewater Treatment with Particulate Biofilm Reactor. Journal of Biotechnology. 80(1): 1-33.
Poh, P. E., Chong, M. F. 2009. Development of anaerobic digestion methods for palm oil mill effluent (POME) treatment. Bioresource Technology. 100: 1-9.

Ramadhani, L. I., Damayanti, S. I., Sudibyo, H., Budhijanto, W. 2018. Kinetics of Anaerobic Digestion of Palm Oil Mill Effluent ( POME ) in Double-Stage Batch Bioreactor with Recirculation and Fluidization of Microbial Immobilization Media Kinetics of Anaerobic Digestion of Palm Oil Mill Effluent ( POME ) in Double-Stage Ba. IOP Conference Series : Materials Science and Engineering.

Saelor, S., Kongjan, P., O-Thong, S. 2017. Biogas Production from Anaerobic of Palm Effluent and Empty Fruit Bunches. Energy Procedia. 138: 717-722.

Shuler, M. L., Kargi, F. 2002. Bioprocess Engineering Basic Concepts ( $\left.2^{\text {nd }} e d.\right)$. Pearson. 